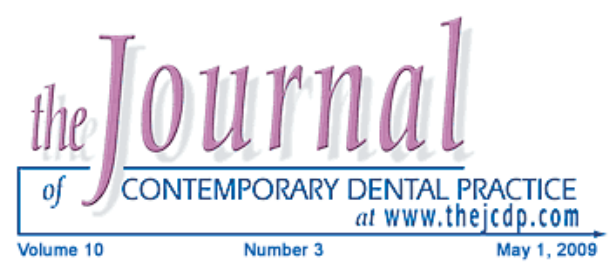

\title{
In vitro Pharmacodynamic Activities of Root Canal Sealers on Enterococcus faecalis
}

\author{
Burak Sagsen, DDS, PhD; Ozgür Er, DDS, PhD; Duygu Esel, DDS, PhD; \\ Gülhan Yagmur, DDS, PhD; Yasemin Altintop, DDS, PhD
}

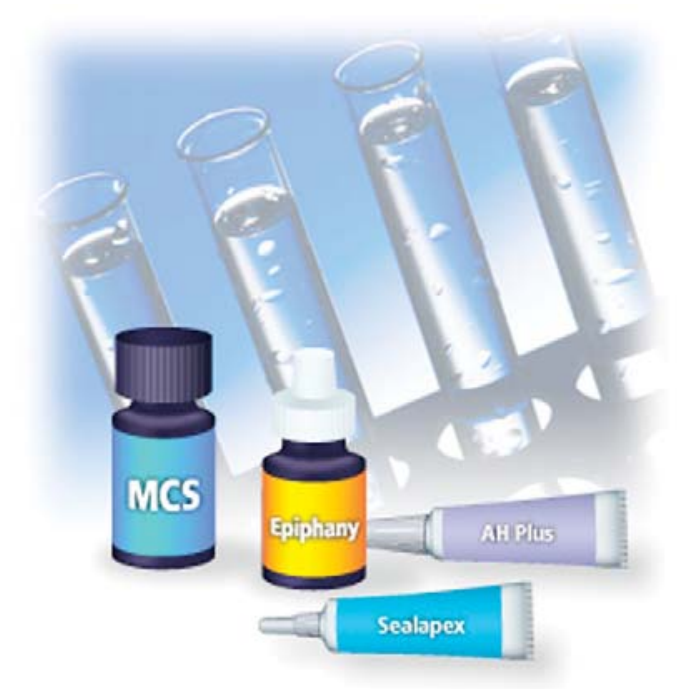

Abstract

Aim: The aim of this study was to evaluate the antimicrobial efficiency of different root canal sealers on Enterococcus faecalis (E. Faecalis) at different time intervals.

Methods and Materials: All sealers used were mixed according to the manufacturers' instructions then $75 \mathrm{mg}$ of each sealer was added to different sterile tubes and evaluated at 20 minutes, 24 hours, 7 days, and 30 days. A time-kill assay (TKA) was used to determine the antimicrobial efficiency of the sealers.

Results: AH Plus and MCS were found to be bactericidal at 20 minutes and 24 hours, but only MCS was bactericidal at the seventh and thirtieth days. Epiphany and Sealapex were found to be bacteriostatic at the seventh and thirtieth days but indifferent at 20 minutes and 24-hours. MCS and AH Plus were both found to be bactericidal in freshly mixed samples, but only MCS was bactericidal at longer time periods. Epiphany Sealer and Sealapex were found to be bacteriostatic at longer time periods but indifferent at 20 minutes and 24 hours.

Conclusion: The antibacterial effect of MCS was greater than the other sealers evaluated.

Clinical Significance: Sealers containing eugenol and epoxy resin might be preferable due to their antibacterial effect.

(c) Seer Publishing 
Keywords: Root canal sealer, Enterococcus faecalis, pharmacodynamic activity, time-kill assay, TKA

Citation: Sagsen B, Er O, Esel D, Yagmur G, Altintop Y. In vitro Pharmacodynamic Activities of Root Canal Sealers on Enterococcus faecalis. J Contemp Dent Pract 2009 May; (10)3:035-042.

\section{Introduction}

The main objective of root canal treatment is to remove microbes in an infected dental pulp and to prevent subsequent reinfection. ${ }^{1-3}$ Microbial organisms may be present not only throughout the pulp chamber but also in areas inaccessible to instrumentation and disinfection such as lateral canals, apical ramifications, crevices, and dentinal tubules. ${ }^{1,4-8}$

If a prepared root canal is completely filled laterally as well as apically, any microorganisms remaining in the dentinal tubules could not survive. ${ }^{9}$ Sundqvist et al. ${ }^{10}$ reported complete root filling with gutta-percha points and sealer after chemomechanical cleaning and disinfection blocks the nutritional source of any remaining microorganisms resulting in their elimination. Microorganisms may be destroyed by the antimicrobial activity of the sealer or the guttapercha points. ${ }^{11-14}$

The root canal filling helps to prevent infection by acting as a barrier against microbial organisms of the oral flora and to stop periapical tissue fluids from leaking into the root canal. ${ }^{10}$ Some root canal sealers elicit an antibacterial activity $^{12,13}$

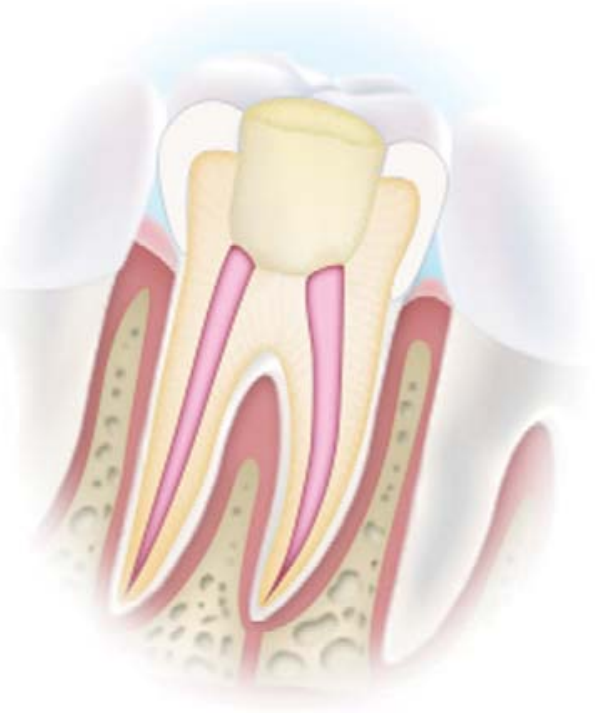

that may contribute to the destruction of intracanal microorganisms. ${ }^{15}$ The highest antimicrobial activity has been shown to occur immediately after the sealer is mixed and then decreased when it was set. ${ }^{16,17}$ However, Kaplan et al. ${ }^{13}$ suggested the possible importance of evaluating the antimicrobial effect of sealers over a longer time interval.

Enterococcus faecalis (E. faecalis) is a resilient bacterium frequently recovered from filled root canals with signs of apical periodontitis. ${ }^{10}$ When established in the dentinal tubules, it is difficult to eliminate this species through root canal medication. Therefore, it might be useful if the sealer exerts some antimicrobial activity during an endodontic treatment procedure.

The time-kill assay (TKA) is a method used to assess the ability of a fixed concentration of an antimicrobial agent to destroy a bacterial isolate under controlled conditions. The kill rate is determined by measuring the number of viable bacteria at various time intervals. The resulting graphic depiction is known as the time-kill curve. ${ }^{18,19}$ While evaluating the antimicrobial activity of root canal sealers, mainly the agar diffusion test (ADT) and direct contact test (DCT) are used. The ADT requires careful standardization of the following factors to maximize accuracy. ${ }^{20}$

- Inoculum density

- Medium content

- Agar viscosity

- Storage conditions of agar plates

- Size and number of specimens per agar plate

- Location and arrangement of specimens on the agar plate

- Adequate contact between specimens and adjacent agar

- Incubation time

- Temperature

The ADT has a semi-quantitative nature and can only be used to measure the activity of soluble 
components, and the test cannot distinguish between the bacteriostatic and bactericidal effects of tested materials. ${ }^{21}$

Using the TKA, a 3-log10-CFU/mL decrease in bacterial colony counts in an antimicrobial solution compared with counts for the growth control is indicative of a bactericidal effect. A decrease in the bacterial colony counts below 3- $\log 10-\mathrm{CFU} / \mathrm{ml}$ are considered to be indicative of a bacteriostatic effect. ${ }^{18,19}$

The aim of this study was to evaluate the pharmacodynamic activities of four different root canal sealers on $E$. faecalis using the TKA method.

\section{Methods and Materials}

\section{Products Tested}

Commercially available root canal sealers included in the study are listed below, and the composition of each product is presented in Table 1.

- AH Plus. An epoxy-based sealer (DeTrey, Zurich, Switzerland)

- MCS. An iodoform and zinc oxide based sealer (Lone Star Technologies, Westport, CT, USA)

- Epiphany. A resin-based sealer (Pentron, Wallingford, CT, USA)
- Sealapex. A calcium hydroxide-based sealer (Sybron Kerr, Romulus, MI, USA)

\section{Preparation of Sealers}

Sealers were mixed according to manufacturers' instructions. Four different sterile tubes were prepared for each sealer by placing $75 \mathrm{mg}$ of each sealer into the tubes using a sterile wood swab. Surface areas of the tested samples were approximately $2 \mathrm{~cm}^{2}$. Samples were aged at 20 minute (freshly mixed), 24 hour, 7 day, and 30 day intervals after mixing in a humid atmosphere at $37^{\circ} \mathrm{C}$.

\section{Time-kill Assay (TKA)}

E. faecalis ATCC 29212 was used in this study. An inoculum was prepared by suspending $E$. faecalis colonies from blood agar in sterile saline to match a 0.5 McFarland standard (approximately $108 \mathrm{CFU} /$ $\mathrm{mL}$ ) using a spectrophotometer at a wavelength of $625 \mathrm{~nm}$. A micropipette was used to inoculate approximately $100 \mu \mathrm{L}$ of bacterial suspension into the four different tubes containing sealer and 900 $\mu \mathrm{L}$ brain-heart infusion broth, resulting in a final inoculum of approximately $107 \mathrm{CFU} / \mathrm{mL}$. The tubes were then vortexed and incubated in ambient air at $35^{\circ} \mathrm{C}$ for 24 hours. One hundred $\mu \mathrm{L}$ samples were taken from the tubes at 0, 1, 6, and 24 hours and

Table 1. Composition of the materials.

\begin{tabular}{|l|l|}
\hline \multicolumn{1}{|c|}{ Sealers } & \multicolumn{1}{|c|}{ Ingredients } \\
\hline Epiphany Primer & Acidic monomer solution in water, HEMA \\
\hline Epiphany Sealer & $\begin{array}{l}\text { Mixture of UDMA, PEGDMA, EBPADMA, and BISGMA resins, silane-treated } \\
\text { bariumborosilicate glasses, barium sulfate, silica, calcium hydroxide, bismuth } \\
\text { oxychloride with amines, peroxide, and photo initiator. }\end{array}$ \\
\hline Resilon Cone & $\begin{array}{l}\text { Acompound of polyester, difunctional methacrylate resin, bioactive glass, } \\
\text { radioopaque fillers, and coloring agent. }\end{array}$ \\
\hline AH Plus Paste A & $\begin{array}{l}\text { Bisphenol-A epoxy resin, bisphenol-F epoxy resin, calcium tungstate, zirconium } \\
\text { oxide, silica, and iron oxide pigments. }\end{array}$ \\
\hline AH Plus Paste B & $\begin{array}{l}\text { Dibenzyldiamine, aminoadamantane, tricyclodecane-diamine, calcium } \\
\text { tungstate, zirconium oxide, silica, and silicone oil. }\end{array}$ \\
\hline Sealapex & Calcium oxide, barium sulfate, and salisilate resin. \\
\hline MCS Canal Sealer & lodoform, Zinc Oxide Eugenol \\
\hline
\end{tabular}




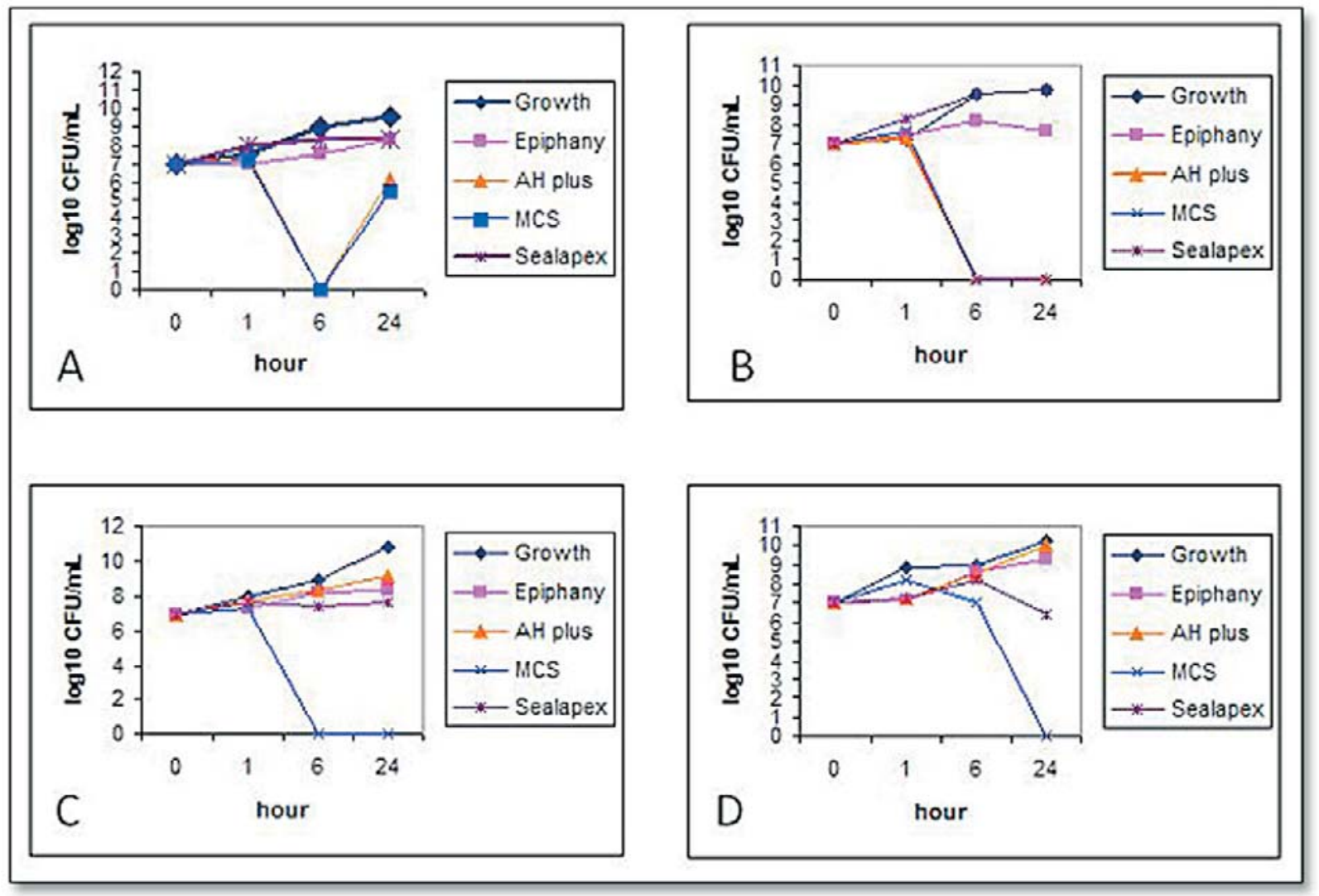

Figure 1. Bactericidal activities of the four sealer using a TKA. A. Test within 20 minutes after mixing the sealers, B. Test at 24 hours after mixing, C. Test at seventh day after mixing, and D. Test at thirtieth day after mixing.

inoculated into another four tubes containing 900 $\mu \mathrm{L}$ brain-heart infusion broth. The main tube was allowed to continue the incubation up to next sample time (1, 6, and 24 hours, respectively). Immediately after inoculation, serial dilutions were performed. Two more tubes containing $900 \mu \mathrm{L}$ of brain-heart infusion broth were used as controls; one without bacteria for a sterility control and the other with bacteria for a growth control.

One hundred $\mu \mathrm{L}$ samples were taken from each dilution tube and used to inoculate two brain heart infusion agar plates. Colonies were counted following 18 hours of incubation at $35^{\circ} \mathrm{C}$. The counts from plates showing 30 to 300 colony forming units (CFUs) were averaged. The average counts were converted to actual CFU per $\mathrm{mL}$ by multiplying the average of raw counts by the dilution factors. CFU per milliliter (y axis) versus time ( $x$ axis) was then plotted on a semilog paper.

\section{Pharmacodynamic Analysis}

In vitro model time-kill curves were determined by plotting mean colony counts (log10 CFU/mL) from each tube versus time. Bactericidal activity (99.9\% kill) was defined as a $3-\log 10 \mathrm{CFU} / \mathrm{mL}$ reduction in the colony count from the original inoculum. Bacteriostatic activity (99.9\% growth inhibition) was defined as a $2-\log 10 \mathrm{CFU} / \mathrm{mL}$ reduction and indifference was defined as the a 1 log10 CFU/mL reduction in the original inoculum. ${ }^{22}$

\section{Results}

Bactericidal activities of the four sealer using a TKA are shown in Figure 1. According to these results, AH Plus and MCS were found to be bactericidal at 20 minutes and 24 hours, but only MCS was bactericidal on the seventh day and thirtieth day. Epiphany and Sealapex was found to be bacteriostatic on the seventh and thirtieth days but indifferent at 20 minutes and 24 hour intervals (Figure 1). 


\section{Discussion}

Microorganisms are considered to be the main etiologic agents in endodontic diseases. ${ }^{23}$ The main objective of root canal therapy is to prevent and treat periradicular inflammation by eliminating microorganisms from the root canal system and to prevent subsequent reinfection. ${ }^{2,15}$ Adequate instrumentation, irrigation, intracanal medicaments, and obturation are common procedures used to eliminate microorganisms from the root canal. ${ }^{24}$ However, Byström and Sundqvist ${ }^{25}$ as well as Ørstavik and Haapasolo ${ }^{26}$ showed bacteria could survive in empty dentinal tubules after a complete biomechanic preparation of a root canal. Furthermore, Sundqvist et al. ${ }^{10}$ reported $E$. faecalis to be an important etiologic agent for endodontic failures and Rocas et al. ${ }^{27}$ demonstrated $E$. faecalis to be strongly associated with persistent infections.

Although E. faecalis does not represent a large percentage of the root canal flora, once it enters the root canal system the microorganisms can demonstrate a high resistance to biomechanic preperation and medicaments and persist after completion of the root canal filling. For this reason, the choice of sealer with high and longterm antimicrobial activity may be advantageous to decrease or avoid future growth of these remaining microorganisms. ${ }^{28,29}$

The incorporation of antimicrobial components into root canal sealers may become an essential factor in preventing the regrowth of residual bacteria and control of bacterial re-entry into the root canal space..$^{20}$ Lai et al. ${ }^{30}$ showed different inhibitory effects may be seen depending on the type of root canal sealers and bacterial strains tested.

AH Plus and AH26 (De Trey Division Dentsply, Weybridge, UK) are basically the same epoxy resin-based root canal sealer except AH Plus reportedly does not release formaldehyde. ${ }^{31}$ In the present study $\mathrm{AH}$ Plus was found to be bactericidal at 20 minutes (freshly mixed) and 24 hours but less bactericidal on the seventh and thirtieth days. The results of freshly mixed and 24 hour AH Plus samples were similar to those found by Cobankara et al. ${ }^{23}$ and Kayaoglu et al. ${ }^{3}$ On the contrary, Pizzo et al. ${ }^{2}$ found a bacteriostatic effect on $E$. faecalis in the 24 hour samples. However, none of these studies were performed

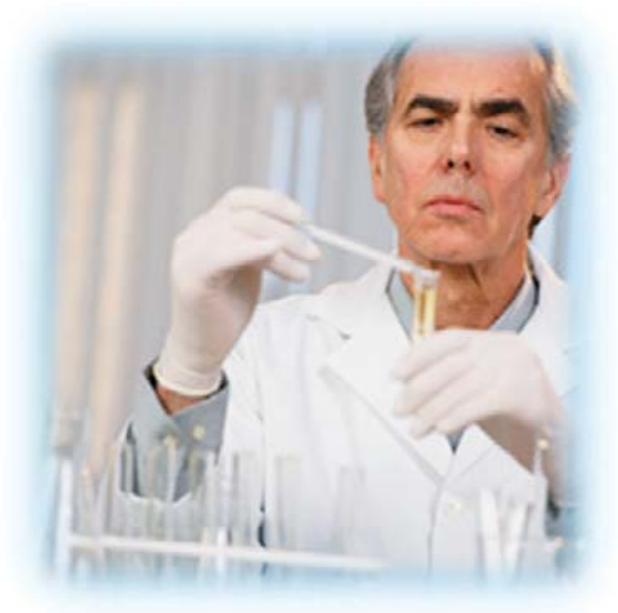

on long-term samples. In one of the long-term studies Kaplan et al. ${ }^{13}$ reported AH Plus to be relatively effective after 40 days. This difference may be due to the methods and the tested microorganisms used to assess the antibacterial activity of sealers. Since the antimicrobial activity of AH Plus may depend on its content of calcium hydroxide the $\mathrm{pH}$ rise may be insufficient to kill E. Faecalis. ${ }^{15}$ An insufficient rise in $\mathrm{pH}$ may be due to the low solubility of AH Plus reported by McMichen et al. ${ }^{32}$

MCS is an iodoform and zinc-oxide contining root canal sealer also found to be bactericidal at 20 minutes and 24 hours but was the only sealer tested that demonstrated bactericidal activity on the seventh and thirtieth days. Due to the slow release of iodine when in contact with body fluids, iodoform is a mild antiseptic material. ${ }^{3}$ MCS contains zinc-oxide eugenol that could be responsible for a strong antimicrobial effect $^{15,24,31}$ which is in agreement with Pizzo et al. $^{2}$ and with Kaplan et al. ${ }^{13}$ who suggest sealers containing eugenol and formaldehyde show high antimicrobial activity.

Epiphany is a new dual curable dental resinbased sealer. Although favorable results were obtained in bacterial leakage studies with this product, ${ }^{33,34}$ no previous study has been done to investigate the antimicrobial activity of Epiphany root canal sealer. The findings of the present study demonstrated Epiphany to be bacteriostatic on the seventh and thirtieth days but indifferent at the 20 minute and 24 hour intervals. This late effect of Epiphany may be due to its calcium hydroxide content. 
Sealapex is a calcium hydroxide-based sealer whose antimicrobial properties are achieved by the release of $(\mathrm{OH})$ - ions. Pure calcium hydroxide with a $\mathrm{pH}$ of 12.5 is a strong antimicrobial. ${ }^{25}$ However, the $\mathrm{pH}$ of Sealapex was 9.14 after 48 hours and hydroxyl ions were not released in high concentrations in freshly mixed samples. ${ }^{25}$ This could explain why calcium hydroxidebased sealers had no significiant antimicrobial effect when freshly applied as was the case in the present study and in a previous report by Kayaoglu et al. ${ }^{3}$ Similarly, the present study found Sealapex had no effect at 20 minutes and 24 hours but it was found to be bacteriostatic at the seventh and thirtieth days.
Like Lai et al. ${ }^{30}$ and Kaplan et al. ${ }^{13}$ the present study found root canal sealers containing formaldehyde and eugenol were more effective against the tested microorganism. Nonetheless, other parameters should be considered when selecting a root canal sealer because root canal sealers with strong antibacterial effects could have cytotoxic or even mutagenic adverse effects.

\section{Conclusion}

The antibacterial effect of MCS was greater than the other sealers evaluated.

\section{Clinical Significance}

Sealers containing eugenol and epoxy resin might be preferable for their antibacterial activity. 


\section{References}

1. Trope M, Bergenholtz $\mathrm{G}$. Microbiological basis for endodontic treatment: can a maximal outcome be achieved in one visit? Endodontic Topics 2002; 1:40-53.

2. Pizzo G, Giammanco GM, Cumbo E, Nicolasi G, Gallina G. In vitro antibacterial activity of endodontic sealers. J Dent 2006; 34:35-40.

3. Kayaoglu G, Erten H, Alacam T, Ørstavik D. Short-term antibacterial activity of root canal sealers towards Enterococcus faecalis. Int Endod J 2005; 38:483-488.

4. Ando N, Hoshino E. Predominant obligate anaerobes invading the deep layers of root canal dentin. Int Endod J 1990; 23:20-27.

5. Sen BH, Piskin B, Demirci T. Observation of bacteria and fungi in infected root canals and dentinal tubules by SEM. Endod Dent Traumatol 1995; 11:6-9.

6. Love RM, Jenkinson HF. Invasion of dentinal tubules by oral bacteria. Crit Rev Oral Biol Med 2002; 13:171-183.

7. Matsuo T, Shirakami T, Ozaki K, Nakanishi T, Yumoto H, Ebisu S. An immunohistological study of the localization of bacteria invading root pulpal walls of teeth with periapical lesions. J Endod 2003; 29:194-200.

8. Clark-Holke D, Drake D, Walton R, Rivera E, Guthmiller JM. Bacterial penetration through canals of endodontically treated teeth in the presence or absence of the smear layer. J Dent 2003; 31: 275-281.

9. Grossman LI. Endodontic practice, 10th edn. Philadelphia: Lea \& Febiger; 1981; 227.

10. Sundqvist G, Figdor D, Persson S, Sjögren U. Microbiologic analysis of teeth with failed endodontic treatment and the outcome of conservative re-treatment. Oral Surg Oral Med Oral Pathol Oral Radiol Endod 1998; 85:86-93.

11. Moorer WR, Genet JM. Antibacteral activity of gutta-percha cones attributed to the zinc oxide component. Oral Surg Oral Med Oral Pathol Oral Radiol Endod 1982; 53:508-517.

12. Heling I, Chandler NP. The antimicrobial effect within dentinal tubules of four root canal sealers. J Endod 1996; 22:257-259.

13. Kaplan AE, Picca M, Gonzales MI, Macchi RL, Molgatini SL. Antimicrobial effect of six endodontic sealers: an in vitro evaluation. Endod Dent Traumatol 1999; 15:42-45.

14. Siqueira JF, Favieri A, Gahyva SMM, Moraes SR, Lima KC, Lopes HP. Antimicrobial activity and flow rate of newer and established root canal sealers. J Endod 2000; 26:274-277.

15. Saleh IM, Ruyter IE, Haapasalo M, Ørstavik D. Survival of Enterococcus faecalis in infected dentinal tubules after root canal filling with different root canal sealers in vitro. Int Endod J 2004; 37:193-198.

16. Georgopoulou M, Kontakiotis E, Nakou M. In vitro evaluation of the effectiveness of calcium hydroxide and paramonochlorophenol on anaerobic bacteria from the root canal. Endod Dent Traumatol 1993; 9:249-253.

17. Siqueira JF, Goncalves RB. Antibacterial activities of root canal sealers against selected anaerobic bacteria. J Endod 1996; 22:79-80.

18. Knapp J, Moody JA. Tests to assay bactericidal activity. In: Eisenberg HD, ed. Clinical Microbiology Procedures Handbook. American Society for Microbiology: Washington DC, USA; 1992; 1-21.

19. NCCLS. Methods for Determining Bactericidal Activity of Antimicrobial Agents; Approved Guideline. NCCLS document M26-A. NCCLS, 940 Wayne, Pennsylvania, USA; 1999.

20. Weiss El, Shalhav M, Fuss Z. Assessment of antibacterial activity of endodontic sealers by a direct contact test. Endod Dent Traumatol 1996; 12:179-184.

21. Tobias RS. Antibacterial properties of dental restorative materials: a review. Int Endod J 1988; 21:155-160.

22. Tenover FC, Weigel LM, Appelbaum PC, McDougal LK, Chaitram J, McAllister S, Clark N, Killgore G, O'Hara CM, Jevitt L, Patel JB, Bozdogan B. Vancomycin-resistant Staphylococcus aureus isolate from a patient in Pennsylvania. Antimicrob Agents Chemother 2004; 48:275-280.

23. Cobankara FK, Altinöz HC, Erganil O, Kav K, Belli S. In vitro antibacterial activities of root-canal sealers by using two different methods. J Endod 2004; 30:57-60.

24. Fuss Z, Weiss El, Shalhav M. Antibacterial activity of calcium hydroxide-containing endodontic sealers on Enterococcus faecalis in vitro. Int Endod J 1997; 30:397-402. 
25. Byström A, Sundqvist $G$. The antibacterial action of sodium hypochlorite and EDTA in 60 cases of endodontic therapy. Int Endod J 1985; 18:35-40.

26. Ørstavik D, Haapasolo M. Disinfection by endodontic irrigants and dressingsof experimentally infected dentinal tubules. Endod Dent Traumatol 1990; 6:142-149.

27. Rocas IN, Siqueira Jr JF, Santos KR. Association of Enterococcus faecalis with different forms of periradicular diseases. J Endod 2004; 30:504-508.

28. Spangberg L, Engstrom B, Langeland K. Biologic effects of dental materials. 3. Toxicity and antimicrobial effect of endodontic antiseptics in vitro. Oral Surg Oral Med Oral Pathol 1973; 36:856-871.

29. Ørstavik D. Antibacterial properties of endodontic materials. Int Endod J 1988; 21:161-169.

30. Lai CC, Huang FM, Yang HW, Chan Y, Huang MS, Chou MY, Chang YC. Antimicrobial activity of four root canal sealers against endodontic pathogens. Clin Oral Invest 2001; 5:236-239.

31. Mickel AK, Nguyen TH, Chogle S. Antimicrobial activity of endodontic sealers on Enterococcus faecalis. J Endod 2003; 29:257-258.

32. Mc Michen FRS, Pearson G, Rahbaran S, Gulabivala K. A comperative study of selected physical properties of five root-canal sealers. Int Endod J 2004; 36:629-635.

33. Shipper G, Ørstavik D, Teixeira FB, Trope M. An evaluation of microbial leakage in roots filled with a thermoplastic synthetic polymer-based root canal filling material (Resilon). J Endod 2004; 30:342-347.

34. Shipper G, Teixeira FB, Arnold RR, Trope M. Periapical inflammation after coronal microbial inoculation of dog roots filled with gutta-percha or resilon. J Endod 2005; 31:91-96.

35. Byström A, Claesson R, Sundqvist G. The antibacterial effect of camphorated paramonochlorophenol, camphorated phenol and calcium hydroxide in the treatment of infected root canals. Endod Dent Traumatol 1985; 1:170-175.

\section{About the Authors}

\section{Burak Sagsen, DDS, PhD}

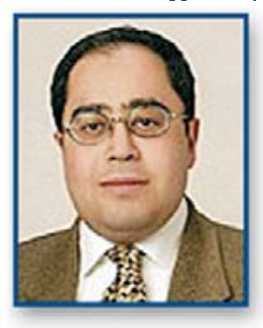

Dr. Sagsen is an Assistant Professor in the Department of Operative Dentistry and Endodontics of the Faculty of Dentistry at the University of Erciyes in Kayseri, Turkey. $\mathrm{He}$ received his graduate training in Endodontics at Ankara University. $\mathrm{He}$ is a member of the Turkish Endodontic Society and the European Endodontic Society.

e-mail: buraksagsen@erciyes.edu.tr

\section{Ozgur Er, DDS, PhD}

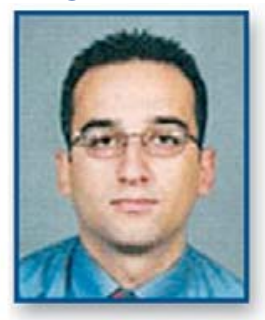

Dr. Er is an Assistant Professor in the Department of Operative Dentistry and Endodontics of the Faculty of Dentistry at the University of Erciyes in Kayseri, Turkey. He received his graduate training in Endodontics at Gazi University in Ankara. Dr. Er is a member of the Turkish Endodontic Society and the European Endodontic Society.

e-mail: ozgurer@erciyes.edu.tr 


\section{Duygu Esel, DDS, PhD}

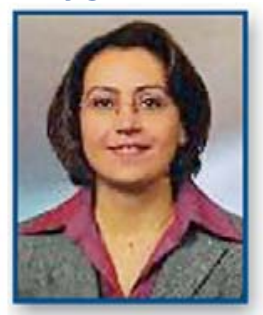

Dr. Esel is an Associate Professor in the Department of Microbiology of the Faculty of Medicine at the University of Erciyes in Kayseri, Turkey. She is a member of the Turkish Society for Disinfection Antisepsis and Sterilization and European Society for Clinical Microbiology and Infectious Diseases.

e-mail: eseld@erciyes.edu.tr

\section{Gülhan Yagmur, DDS, PhD}

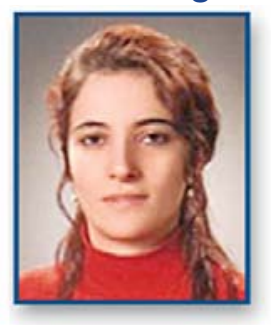

Dr. Yagmur is a physician in the Department of Microbiology of the Faculty of Medicine at the University of Erciyes in Kayseri, Turkey. She is a member of the Turkish Society for Microbiology.

e-mail: gyagmur@erciyes.edu.tr

\section{Yasemin Altintop, DDS, PhD}

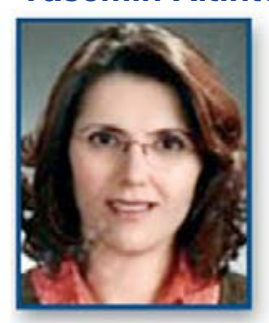

Dr. Yasemin Altintop is a physician in the Department of Microbiology of the Faculty of Medicine at the University of Erciyes in Kayseri, Turkey. She is a member of the Turkish Society for Microbiology.

e-mail: yaltintop@erciyes.edu.tr 